\title{
AN ANALYSIS OF FIGURATIVE LANGUAGE IN POETRY BY MAYA ANGELOU
}

\author{
Asmara Nengke Anggiamurni \\ Faculty of Education, Universitas PGRI Madiun, Kota Madiun, East Java 63118, Indonesia \\ (asmara.na@unipma.ac.id)
}

\begin{abstract}
Figurative language is used to beautify literary work especially the poems. It can make the poems more interesting and unique. But some readers cannot identify figurative language used in poetry. The poem's readers, read, analyze, and interpret poetry without considering the use of figurative language. The objectives of the research were to explain the kinds of figurative language used in selected poems by Maya Angelou and to explain how the use of figurative language in Maya Angelou's poems. This is qualitative research with content analysis. This approach offered to analyze data by choosing some poems by Maya Angelou, reading the poems, identifying the figurative language used in the poems, then analyzing the figurative language used in the poems. In the stage of analyzing figurative language in the Maya Angelou's poems, the researcher was grouping them based on the figurative language used in each poem. In analyzing data, the researcher analyzed every figurative language that is found in the poems and the last drawing conclusion based on the result of data analysis. This research revealed that there were figurative languages in every selected poem by Maya Angelou. Figurative languages used in the poems were varying. Each poem had characteristics so that the use of figurative language was also diverse. This research will give advantages for the readers especially to the lectures and the college students, and it is hoped that will be more research which analyzes figurative language not only in poetry but also in another literary work.
\end{abstract}

Keywords: Figurative Language; Maya Angelou, Poetry Analysis

First Received:

(July 31, 2020)
Final Proof Received:

(September 30, 2020)

\section{INTRODUCTION}

Some people are accustomed to writing beautiful sentences in the caption of their social media. They usually upload a photograph and then put some beautiful poetic sentences to attract others. It makes them popular. For those who cannot write poetical sentences, they will take a lyric of a song or someone else's poetry. Most of them quote the lyrics of the song or poetry without knowing the meaning. They put it in their caption because of its beautiful word order.

The meaning of poetry is not as clear as the meaning of other literary writing. Wainwright (2004: 22) said that poetry is a part of a functioning and the gesturing of the words we use every day, but it is also set aside. It means that diction in poetry is not the same as daily language expressions which have lexical meanings and literal purposes. It can be said that the poet used language in his/her poetry by using more complex meaning language. The poetry is written in poetic language but anyone else does not know the meaning beyond. 
Poetry expresses the idea and feeling of the poet by considering diction, figurative language, rhyme, rhythm, and other elements. Poets' thoughts and feelings are dealing with their imaginations and experiences. They often used the implicit words or sentences in their work.

Based on Drew (1959: 15), poetry is the earliest and remains the most concentrated and intense form of communication among arts and language. In line with Wainwright Wainwright (2004: 5) who explains that reading or writing poetry offers a practicing awareness of the problems of language and meaning. It means that reading poetry does not about the beauty of the words line by line. Reading or writing poetry needs an understanding of the language used. One element which cannot be separated from poetry and language is figurative language.

According to Perrine (1973: 6), figurative language is defined as any way of saying something other than an ordinary way. It means that figurative language has some meanings that differ from the literal meaning. The figurative language is mostly used in poetry because it will express the language behind the ordinary language to beautify the poetry. Actually, the use of language in poetry is free. But the use of figurative language can make the poet write a beautiful diction. Because of the use of figurative language in poetry, the researcher analyzes the application of figurative language in some poems.

There are so many studies about figurative language. It is being studied because it can be found in songs, stories, poetry, even in news. One of inspired the researcher was the study from Tira Nur Fitria (2018), entitled Figurative language used in One Direction's Album Entitled Up All Night. She analyzed and found figurative language in all song lyrics of one album. She found that most of the figurative language that happened in One Direction's song was anaphora and epiphora. Another research was from Cicih Nuraeni and Putri Amalia Peron (2017). In their study, they analyze figurative language in Kelly Darrow' Poetry. Their study almost the same as this research because they analyze poetry from a woman poet. The difference between those researches with this study is in the poetry that was analyzed. The mentioned researchers do not use Maya Angelou's poetry as the subject of their research.

This study also analyses the figurative language used in some poetries of Maya Angelou. Maya Angelou is an American poet, storyteller, and artist. She had written many poetries. In theatre, she produced, directed, and starred some plays. Besides composed poetries, she wrote some screenplays, lyrics for the musical play, and also her biography. Maya Angelou is one of the brightest women poets. She wrote so many poems on various themes, such as love, poverty, hope, sadness, hope, and any others. She was productive in literary works and was active as a human rights association. In 2013 she received Literarian Award for her contributions to the literary community. She passed away in 2014. 
Some of Maya Angelou's poetry used in this research was taken from her own poems' book compilation entitled The Complete Collected Poems of Maya Angelou. The researcher takes some poetry randomly and then analyzes the figurative language used in that poetry.

\section{LITERATURE REVIEW}

\section{Poetry}

Roberts and Jacobs (1995: 547) describe poetry and poem as a wide variety of spoken and written forms, styles, and patterns, and also a wide variety of subjects. Poetry may only have some elements after being analyzed. But it usually has deep meaning. Due to the fact of the variety of some patterns and elements, it is not possible to make a single comprehensive definition of poetry.

Ollila andJantas (2006) stated that poetry is any kind of verbal or written language that is structured rhythmically and is meant to tell a story. It can be seen in books, magazines, or any other media that some poems use short and incomplete sentences. The poem is usually arranged in lines, but does not observe in rhythmical patterns, nor does it rhyme. It does not mean that they have not had rhyme, meter, rhythm, imagery, diction, or symbolism, and so on. Short sentences can show the reader that the poem has richer, finer, more powerful, and deeper meaning that other literary works. It can be concluded that the language used in the poem is extra-condensed that the language of prose and drama in the way it gives the message. The most necessary component about it is that, as it engages us and amuses us, it also rings of fact.

Some poets write poetry based on their experience and imagination then pour it into the words. Even they do not think about the elements, it attached automatically in their works. It makes reading and understanding poetry is not as easy as learning short stories, drama, or the others because the subject of poetry is consist of figurative languages and connotation phrases or clauses so it makes difficult to be interpreted

\section{Figurative Language}

One element of poetry is language. Language in poetry makes it more precious and powerful. It usually uses unique, meaningful, and beautiful words to attract the reader. Language elements in poetry include imagery, diction, and figurative language. In this research, the researcher focuses on the use of figurative language. Thus, this is the part of the explanation about figurative language.

Some linguists have their own opinions in divide the kind of figurative language. Perrine (1983) in his book divided figurative language into ten kinds; they are metaphor, simile, synecdoche, personification, metonymy, allegory, hyperbole, irony, symbol, and paradox. Based on the book of Rozakis (1995) figurative language divided into allegory, ambiguity, apostrophe, conceit, connotation and denotation, contrast, metaphor, irony, 
hyperbole, irony, litotes, metonymy, onomatopoeia, oxymoron, personification, sarcasm, simile, symbolism, synecdoche, synaesthesia, transferred epithet, and understatement. In his book, Keraf (2008) mentions so many kinds of figurative language and divided them into 4 main categories. There are comparisons, contrast, relationship, and repetition.

There are many kinds of figurative language as stated above, but the researcher will focus on ten figurative languages. The explanations of every kind are taken from some linguists, books, or sources. Figurative language used in this part will be used as the tool to examine the poetry of Maya Angelou. The explanation is as follows:

\section{a. Metaphor}

According to Wainwright (2005: 153) metaphor is saying one thing in terms of another which has the same characteristic. Daily speech, prose, and poetry often try to use a metaphor. Metaphor is used in poetry is used when a writer feels that two terms are identical instead of merely similar. It is a comparison but does NOT use like or as to make the comparison.

Example: All the world's a stage (Shakespeare); The language that is lace (Eavan Bolan).

\section{b. Personification}

Personification is a kind of figure of speech that describes things such as alive or having humanity characteristics (Keraf, 2008: 140). Personification gives human characteristics to inanimate objects, things, animals, or ideas. It shows an analogy to draw a thing as if human characteristics.

Example: The night was creeping on the ground! She crept and did not make a sound (James Stephens).

\section{c. Hyperbole}

Tjahjono (2010: 65) explains that hyperbole is an exaggeration utterance. It is used to state something or situation exaggeration not intended to be taken literally. Exaggeration or overstatement is used to affirm something in a very different thing and to create a dramatic effect. It is used to make the object is greater than the real object.

Example: In faith, I do not love thee with mine eyes, for they in thee a thousand errors note (Shakespeare).

\section{d. Metonymy}

Keraf (2008: 140) states that metonymy is a figurative language that using a specific word to explain other words because it has a very close relationship. Metonymy uses to take the name or brand of one object for another to which has relation. It replaces the exact word with something related to an object, thing, or idea. It means one word is being substituted with another word that has a close association.

Examples: He buys a new Chevrolet. 
e. Simile

A simile is an expression that compares something to another else by the use of a function word, such as like, than, resemble, seem, or as (Keraf, 2008: 138). A simile uses a direct comparison between some ideas which are unlike in their essence. Example: My love is like a red, red rose (Robert Burn).

\section{f. Synecdoche}

Synecdoche means collectively receive. Synecdoche has two types, they are synecdoche pars prototo and synecdoche totem pro parte. In synecdoche pars prototo the writer uses parts of something to state the whole of the parts. Besides, synecdoche totem pro parte uses the whole parts of something to state the a little parts. (Keraf, 2008: 142)

Example:

We spoke all night in tongues, in fingertips, in teeth (Robert Hass) (Synecdoche pars prototo).

SMA 2 hits SMK 4 3-1 on the final basketball championship (Synecdoche totem pro parte).

\section{g. Irony}

The irony statement is the statement of untrue. It is interpreted by the hearer from the meaning of the speaker, if irony not praise but usually criticism (Dancygier \& Sweetser, 2014). This is a kind of result from the contrast statement between factual meaning and the suggestion of another meaning. Example: Water, water, everywhere, nor any drop to drink (Samuel Taylor Coleridge).

\section{h. Paradox}

Paradox means deliver two kinds of contradictory but it reveals the real fact that makes sense the speaker or the writer uses absurd words (Kennedy \& Gioia, 2002). A paradox is a rhetoric term for a situation or statement that seems contradictory or absurd but may contain insight into life (McArthur, Lam-McArthur, \& Fontaine, 2018: 48). The main purpose is used to attract others' attention and proce very dramatic impacts.

Example: Ignorance is strength (George Orwell, 1984).

\section{i. Symbolism}

Symbolism is a kind of figurative language that using the symbol of animals, plants, or things fo substitute anything else. Symbolism was established from the result of personal experiences, expressions, and fantasies. (Alm-Arvius, 2003). The symbol is a literary device which consists of some meaning layers represents some other aspects, concepts, or traits. It is using an object, idea, or action that has some meanings more than its literal meaning. The symbol usually uses familiar things in people's daily life.

Examples: The dove is a symbol of peace. 


\section{j. Alliteration}

Alliteration is kind of figurative language that has repeated some consonants. (Keraf, 2008: 130). This figurative language is the repetition of the initial consonant. There should be at least two repetitions in a row.

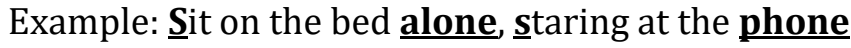

\section{METHOD}

The design of content analysis with a qualitative approach is used by the researcher to conduct this research. Content analysis means a process of categorizing data into a similar category. Categorizing the subject research is to identify patterns between variables (Given, 2008). After collecting the subject into the same category, the researcher analysed it. Denzin and Lincoln (2018:3) claim that qualitative research involves an interpretive and naturalistic approach. This means that the researcher study things naturally to make sense of some phenomena. In terms of the meanings, people bring to them. It means that the qualitative approach uses to increase information into a particular phenomenon; it can be a process, a sense, or even a belief.

The subject of the study were five selected poetries by Maya Angelou, they were: "Come. And be My Baby", "in a Time", "To a Freedom Fighter", "When I Think about Myself", "London". The researcher chose the random poetry among Maya Angelou collection poems in her book The Complete Collected Poems of Maya Angelou (Angelou, 1994).

The main data of this research were figurative languages found in the five selected poetries by Maya Angelou. First, the researcher selected randomly five poetries of Maya Angelou in her book. Then, the poetries were read line by line to find the figurative language and then classify them. In analyzing the data of research, the researcher used a qualitative approach. By using this approach the researcher was able to study the contextual factors, symbolic dimensions, and meaning. The researcher also can find flexibility in unexpected ideas during research and explore processes effectively.

\section{RESULTS AND DISCUSSION}

\section{Results}

This part showed the result of the data analysis of the figurative language found in the poetry by Maya Angelou. The researcher analysed the figurative language in the lyric of poems by Maya Angelou. The figurative language of "Come. And be My Baby" can be seen in table 1. The figurative language of "In a Time" can be seen in table 2. The figurative language of "A Freedom Fighter" can be seen in table 3. The figurative language of "When I Think about Myself", and "London" can be seen in table 4 and table 5. 
Table1.

The analysis of figurative language in "Come. And be My Baby"

\begin{tabular}{lll}
\hline No & Line in Poetry & Figurative Language \\
\hline 1. & And folks are smoking anything that'll burn (Line 3) & Synecdoche \\
2. & Some people wrap their life around a cocktail glass (Line 4) & Personification \\
3. & The paper is full of every kind of blooming horror (Line 11) & $\begin{array}{l}\text { Personification } \\
\text { Synecdoche }\end{array}$ \\
\hline
\end{tabular}

Table 2.

The analysis of figurative language in "In a Time"

\begin{tabular}{lll}
\hline No & Line in Poetry & Figurative Language \\
\hline 1. & In a time of secret wooing (line 1) & $\begin{array}{l}\text { Synecdoche } \\
\text { Personification } \\
\end{array}$ \\
2. & My heart is torn asunder (Line 4) & Hyperbole \\
3. & Half-truths told an entire lies (Line 7) & Paradox \\
4. & My conscience echoes thunder (Line 8) & Personification \\
5. & In a time when kingdom come (Line 9) & Synecdoche \\
6. & Joy is brief as summer's fun (Line 10) & Simile \\
7. & Happiness its race has run (Line 11) & Personification \\
8. & Then pain stalks to plunder (Line 12) & Personification \\
\hline
\end{tabular}

Table 3.

The analysis of figurative language in "A Freedom Fighter"

\begin{tabular}{lll}
\hline No. & Line in poetry & Figurative Language \\
\hline 1. & I sip the tears your eyes fight to hold (Line 2) & Personification \\
2. & A cup of lees, of henbane steeped in chaff (Line 3) & Personification \\
3. & Your breast is hot (Line 4) & Symbol \\
4. & Your anger black and cold (Line 5) & Symbol \\
5. & Through evening's rest, you dream (Line 6) & Personification \\
6. & I hear the moans, you die a thousands' death (Line 7) & Hyperbole \\
7. & When cane straps flog the body (Line 8) & Personification \\
\hline
\end{tabular}

Table 4.

The analysis of figurative language in "When I Think about Myself"

No. Line in poetry $\quad$ Figurative Language

1. I almost laugh myself to death (Line 2)

Paradox

2. My life has been one great big joke (Line 3)

Irony

3. A dance that's walked (Line 4)

Metaphor

4. A song that's spoke (Line 5)

5. I laugh so hard I almost choke (Line 6)

Metaphor

6. Sixty years in this folks' world (Line 8)

Paradox

Synecdoche 
7. I laugh so hard I nearly died (Line 16) Paradox

8. I laugh until I start to crying (Line 20) Paradox

Table 5.

The analysis of figurative language in "London"

\begin{tabular}{lll}
\hline No. & Line in poetry & Figurative Language \\
\hline 1. & London is very queer place (Line 2) & Synecdoche \\
2. & Mighty queer (Line 3) & Irony \\
3. & A million miles from jungle (Line 4) & Hyperbole \\
4. & and the British lion roars (Line 5) & Synecdoche \\
5. & in the stone of Trafalgar Square (Line 6) & Paradox \\
6. & Mighty queer (Line 7) & Irony \\
7. & at least a condition removed from Calcutta (Line 8) & Metonymy \\
8. & But old men in Islington and (Line 9) & Metonymy \\
9. & in too-large sweaters dream (Line 10) & Hyperbole \\
10. & of the sunrise days of the British Raj (Line 11) & Metonymy \\
11. & Awfully queer (Line 12) & Hyperbole \\
12. & Centuries of hate divide St. George's channel and Gaels & Hyperbole \\
& (Line 13) & Metonymy \\
13. & Sweet tea and grow to fight for their Queen (Line 15) & Paradox \\
14. & Mighty queer (Line 16) & Irony \\
\hline
\end{tabular}

In this part, the result of the data analyzed is presented by the researcher. There are five selected poetries written by Maya Angelou. Each poetry has been analyzed in every table. In the first poetry, Come. And be My Baby, it was found 2 personifications and 2 synecdoches. In the second poetry, In a Time, it was found 2 synecdoches, 4 personifications, 1 hyperbole, 1 paradox, and 1 simile.. in the third poetry, A Freedom Fighter, it was found 4 personifications, 2 symbols, and 21 hyperbole. In the fourth poetry, When I Think about Myself, it was found 4 paradoxes, 1 irony, 2 metaphor, and 1 synecdoche. in the last poetry, London, it was found 2 synecdoche, 3 irony, 4 hyperboles, 1 paradox, and 4 metonymies.

\section{Discussion}

In this part, the researcher give further explanation about the data which had been presented in the previous part. This part was started by giving the summarize of the whole data. The summarize was presented in table 6 . Then, it would be followed by the explanation. 
Table 6.

Summary of Findings in Five Selected Poetry

\begin{tabular}{|c|c|c|c|c|c|}
\hline No & $\begin{array}{l}\text { Kinds of Figurative } \\
\text { Language }\end{array}$ & $\begin{array}{l}\text { Founds in } \\
\text { Poetry }\end{array}$ & $\Sigma$ & $\begin{array}{l}\text { Each language } \\
\text { feature in each } \\
\text { poetry }(\%)\end{array}$ & $\begin{array}{l}\text { Each language } \\
\text { feature (\%) }\end{array}$ \\
\hline 1. & Metaphor & $\mathrm{P} 2$ & 2 & 4.6 & 4.6 \\
\hline \multirow[t]{3}{*}{2.} & Personification & $\mathrm{P} 1$ & 2 & 4.6 & 23.3 \\
\hline & & P2 & 4 & 9.3 & \\
\hline & & P3 & 4 & 9.3 & \\
\hline \multirow[t]{3}{*}{3.} & Hyperbole & $\mathrm{P} 2$ & 1 & 2.3 & 13.9 \\
\hline & & P3 & 1 & 2.3 & \\
\hline & & P5 & 4 & 9.3 & \\
\hline 4. & Simile & $\mathrm{P} 2$ & 1 & 2.3 & 2.3 \\
\hline 5. & Metonymy & P5 & 4 & 9.3 & 9.3 \\
\hline \multirow[t]{4}{*}{6.} & Synecdoche & $\mathrm{P} 1$ & 2 & 4.6 & 16.3 \\
\hline & & $\mathrm{P} 2$ & 2 & 4.6 & \\
\hline & & P4 & 1 & 2.3 & \\
\hline & & P5 & 2 & 4.6 & \\
\hline \multirow[t]{2}{*}{7.} & Irony & P4 & 1 & 2.3 & 9.3 \\
\hline & & P5 & 3 & 7.0 & \\
\hline 8. & Symbol & P3 & 4 & 9.3 & 9.3 \\
\hline \multirow[t]{3}{*}{9.} & Paradox & $\mathrm{P} 2$ & 1 & 2.3 & 11.6 \\
\hline & & $\mathrm{P} 4$ & 3 & 7.0 & \\
\hline & & P5 & 1 & 2.3 & \\
\hline \multirow[t]{2}{*}{10.} & Alliteration & - & - & - & - \\
\hline & Total & & 43 & $100 \%$ & $100 \%$ \\
\hline
\end{tabular}

Note:

P1: Come. And be My Baby

P2: In a Time

P3: To a Freedom Fighter

P4: When I Think about Myself

P5: London

From table 6 it can be seen that one kind of figurative language, alliteration, was not found in all poetries. Some figurative languages only appeared in each poetry. Metaphor and simile were only seen in poetry In a Time. Metonymy was only seen in poetry "London". The symbol was only seen in poetry To a Freedom Fighter. It means that not every language feature can be applied every time the author writes the poetry.

Some figurative languages were identified in some poetry. Irony can be found in "When I Think about Myself and London". Personification can be found in three poetries (Come. And be My Baby, In a Time, To a Freedom Fighter). Hyperbole can be found in three poetries (In a Time, To a Freedom Fighter, London). Paradox can be found in three 
poetries ("In a Time”, "When I Think about Myself", "London"). Synecdoche was the most often used of all. It can be found in "Come. And be My Baby", "In a Time, When I Think about Myself", "London."

The personification was used the most in five selected poetries by Maya Angelou. There are three poetries used personification. The percentage of all poetry can be seen in the last column in table 6 . It will be discussed from the lowest percentage to the highest. The smallest percentage was simile $(2.3 \%)$. Simile can be found once in one poetry (In a Time). The next was metaphor (4.6\%) and was found twice in poetry (In a Time). There are metonymy, irony, and symbol which are placed in the third (9.3\%). Each of them was found four times; Metonymy was found four times in the fifth poetry (London), irony was found once in the fourth poetry (When I Think about Myself) and three times in fifth poetry (London, symbol) was found four times in the third poetry (To a Freedom Fighter). After that Paradox placed the fourth rank (11.3\%). It was found once in the second poetry (In a Time), three times in the third poetry (To a Freedom Fighter), and once in the fifth poetry (London). The next figurative language was hyperbole (13.9\%). It happened in three poems, once in In a Time, once into a Freedom Fighter, and four times in London. Then, synecdoche was in the top two (16.3\%). It was found in four poems; twice in the first poetry (Come. And be My Baby), twice in the second poetry (In a Time), once in the fifth poetry (When I Think about Myself), and twice in the fifth poetry (London). Figurative language that was found the most was personification (23.3\%). It was found two times in the first poetry (Come. And be My Baby), four times in the second poetry (In a Time), and four times in the third poetry (To a Freedom Fighter).

In Fitria study (2018), it was found that the most figurative language found in her study were anaphora and epiphora. The difference between this research and Fitria study was the sum of the figurative language types, the sum of the research subjects, and the type of research subject. In this research, the researcher has 10 figurative languages to be analyzed, in her study she had 13. In this research, the researcher analyzes 5 selected poems by Maya Angelou, but her study she had 9 song lyrics to be analyzed. In her study, Fitria focuses on figurative language and then analyze the lyrics. It is different from this research because this research focuses on the poetry then analyze them to find the figurative in each line. Those two kinds of analysis are good because it has their own special thing. Song lyrics and poetry are almost the same. But usually, poetry has a deeper meaning than song lyrics. In song lyrics, there are fewer figurative languages than in poetry. So it is easy to focus on figurative language when analyzing song lyrics. In this research, the researcher focuses on each poetry because in one poetry it will be found more than one figurative language.

In Nuraeni and Peron (2017), it was found that Kelly Darrow uses metaphor, simile, irony, personification, and hyperbole. The way they analyze poetry is also almost the same as this research. They analyze Kelly's poetry line by line to find the figurative language. 
The theme of poetry was analyzed in their study and this research was different. Kelly's poetry is about social life and Maya Angelou's poems are mostly about love.

The findings in this research are different from those two previous studies. The first previous study focus on song lyrics and the second one is focused on poetry but from a different writer. The various result will make various knowledge for the reader.

\section{CONCLUSION}

Some figurative languages are found in poetry by Maya Angelou. The totals of figurative languages found in Maya Angelou's selected poems were 43 sentences. Metaphor consists of 2 sentences, personification consists of 10 sentences, hyperbole consist of 6 sentences, simile consist of 1 sentence, metonymy consists of 4 sentences, synecdoche consists of 7 sentences, symbolism consists of 4 sentences, paradox consist of 5 sentences, alliteration did not appear in any sentence. All ten figurative languages were not always found in all poems. Among the ten figurative languages, alliteration there was not found any. Some figurative languages only can be found in one poem. Some others can be found in more than one poem. It also can be concluded that one poem could only consist of two figurative languages. Next, five selected poetry of Maya Angelou tells about love, struggle, freedom, survival, and hope. All those five poems can inspire the reader. The reader needs to read and try to understand the meaning of the poems so that they can catch what the author wants to deliver in her poetry. The poems can also be the motivation and inspiration for those who want to express their feeling in poetry. It is because Maya Angelou wrote her poems used simple sentences.

\section{REFERENCES}

Alm-Arvius, C. (2003). Figures of Speech. Lund: Studentlitteratur.

Angelou, M. (2013). The Complete Collected Poems. London: Hachette UK.

Dancygier, B., \& Sweetser, E. (2014). Figurative Language. New York: Cambridge University Press.

Denzin, N. K., \& Lincoln, Y. S. (2018). The SAGE Handbook of Qualitative Research (5 ed.). London: SAGE Publications.

Drew, E. A. (1959). Poetry: A Modern Guide to Its Understanding and Enjoyment. New York: W. W. Norton, Incorporated.

Fitria, T. N. (2018). Figurative Language Used in One Direction's Album Entitled up All Night. English and Literature Journal, 5(1), 69-79. doi: 10.24252/elite.v5i1a7.

Given, L. M. (2008). Qualitative Research Method. California: SAGE Publications.

Kennedy, X. J., \& Gioia, D. (2002). An Introduction to Poetry. London: Longman.

Keraf, G. (2008). Diksi dan Gaya Bahasa. Jakarta: Gramedia Pustaka Utama.

McArthur, T., Lam-McArthur, J., \& Fontaine, L. (2018). Oxford Companion to the English Language. Oxford: Oxford University Press. 
Asmara Nengke Anggiamurni, An Analysis of Figurative Language in Poetry ...

Nuraeni, C., \& Peron, P. A. (2017). Figurative Language in Kelly Darrow's Selected Poetry. Wanastra: Jurnal Bahasa dan Sastra, 9(2), 122-129. doi: 10.31294/w.v9i2.2480.

Ollila, B., \& Jantas, J. (2006, Desember 15). The Definition of Poetry. Accessed from https://joejantas.files.wordpress.com/2011/04/the-definition-of-poetry1.pdf.

Perrine, L. (1973). Sound and Sense: An Introduction to Poetry. New York: Harcourt Brace Jovanovich.

Perrine, L. (1983). Literature: Structure, Sound, and Sense. New York: Harcourt Brace Jovanovich.

Roberts, E. V., \& Jacobs, E. H. (1995). Literature. New Jersey: Prentice Hall International.

Rozakis, L. (1995). How to Interpret Poetry. New York: A Simon \& Schuster Macmillan Company.

Tjahjono, T. (2010). Mendaki Gunung Puisi ke Arah Kegiatan Apresiasi. Malang: Banyumedia Publishing Anggota IKAPI.

Wainwright, J. (2004). Poetry the Basic. New York: Routledge. 